\title{
Indledning Medier, offentligheder, køn
}

\author{
Af Michael Nebeling Petersen, \\ Louise Yung Nielsen og SusanNe NørgaARD
}

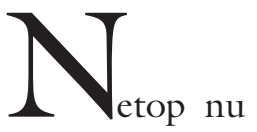

fylder Lars Løkke Rasmussens bilagssager og position som leder af Venstre medierne. De store dagblades netaviser har i de sidste par døgn uploadet nye artikler $\mathrm{i}$ en lind strøm. Især artiklerne, hvor "anonyme kilder fra Venstres folketingsgruppe" undsiger Lars Løkke Rasmussen, understreger, at relationen mellem medier og virkelighed ikke er kausal lineær, men snarere er kompleks og består af en udveksling mellem sfærer (se fx Kember \& Zylinska 2012).

Når dagbladenes netaviser bringer disse artikler bidrager de til det politiske kredsløb og er med til stille spørgsmålstegn. Således er mediernes udladninger ikke blot vinklet formidling af "virkeligheden", de er snarere selv med til at performe politik og til at gribe ind i en politisk materiel verden og påvirke den. At forstå mediernes artikler som diskursive udlægninger af udviklingen $\mathrm{i}$ partiet Venstre er i bedste fald naivt, snarere må medierne forstås som aktive medspillere. Det bidrager ligeledes til forståelsen af 
medierne som handlende aktører, at det er kommet frem at ledende personer i Venstre har brugt aviser og TV til at fremme egne interesser ved at plante historier $\mathrm{i}$ diverse medier.

På den måde må både 'medierne' og 'politikerne' forstås som aktive producenter af politiske virkeligheder, udviklinger og forståelser. Men også mediets form træder frem: Netaviser, Facebook, Twitter, livefeed og hastige nyhedskanaler har i deres (nye) materielle former givet nye muligheder for politiske udviklinger både i stadig stigende hastighed, men også i nye konfigurationer, hvor forholdet mellem producent, medieudtryk, mediekanal og modtager for alvor er blevet mudret og gensigt konstituerende.

Dette nummer af Kvinder, Køn é Forskning handler om medier og offentligheder. Artiklerne i nummeret viser, hvordan nye medier skaber (mulighed for) nye alternative offentligheder, men også hvordan offentligheder bruger nye medier. Og temanummerets to artikler og essay viser på hver sin måde, hvordan det private og offentlige tegner hinanden.

\section{FANKULTURER, NYE MEDIER OG OFFENTLIGHEDER}

Feministisk teori har længe argumenteret for, at offentligheden ikke bare en neutral mødeplads, men snarere en kampplads, hvor bestemte kroppe og kropsmærker allerede er dømt uden for (se fx Fraser 1990). Foruden at pege på de ideologier og hegemonier, der tegner 'den neutrale' offentlighed, har feministisk teori således også interesseret sig for modoffentligheder og former for fællesskab, som tegnes gennem andre erfaringer og $i$ andre rum end de dominante (se fx Berlant 1997 eller Warner 2005).

Senest har Athena Farrokhzad, i sin anmeldelse af Yahya Hassans digtsamling af samme navn (2014), peget på, at der er visse erfaringer, som ikke kan deles i en hvid offentlighed, da "mina förövare ser ut som jag”. Farrokhzad viser, hvordan offentlig- heden definerer hvad, der bliver muligt at forstå og hvilke former for viden, der allerede dømmes udenfor.

Det er derfor ingen overraskelse, at de to artikler i dette nummer centrerer omkring offentligheder, som ikke ved første øjenkast er synlige i den dominante offentlighed. Vi vil i dette nummer komme tæe på "sugar cubes" og "little monsters", som er betegnelser for "followers" eller fans af hhv. Sugar Mama og Mother Monster. Allerede i sprogvalget finder vi en alternativ offentlighed, hvor fx monsteret approprieres, ligesom familiære kategorier ("mother", “mama”) og relationer (voksen-barn) omformes og gentænkes i andre former.

De blogs og internetfora, der behandles i dette nummer, giver mulighed for at sådanne modoffentligheder eller alternative offentligheder kan tage form. De nye medier skaber således rum, hvor ikke-normative eller alternative former kan repræsenteres, men også skabes gennem selvsamme medieformer.

Farrokhzads anmeldelse medførte en skarp debat om hvorvidt offentligheden er en neutral arena, hvor forskellige meninger kan mødes, eller om offentligheden må forstås som domineret af en hvid, heteroseksuel, mandlig udsigelsesposition. Forfatterne af essayet til dette nummer var blandt debattørerne, som mente det sidstnævnte. Deres tekster kunne ikke blive trykt i de etablerede medier, og de valgte derfor at starte deres egen blog (Bissenbakker, Danbolt og Nebeling Petersen 2014). Således tegner også essayets forfattere en modoffentlighed, der gennem blogmediet insisterer på en anden diskurs, andre affektive tilhørsforhold og andre logikker.

Modoffentligheder har eksisteret lige så længe, der har eksisteret dominerende offentligheder. Men gennem de nye medier muliggøres andre forbindelser, som både giver rum til allerede etablerede (mod)offentligheder såvel som skaber disse (mod)offentligheder gennem og i mediets muligheder og arkitektur. 


\section{(NYE) MEDIER, (NYE) KROPPE}

Vi opfatter måske umiddelbart eller oftest relationen mellem medier og mennesker som en let afkodelig, kausal og lineær relation mellem de to. Fx at medier gør noget ved mennesker. At modemagasiner giver unge piger urealistiske idealer og forårsager spiseforstyrrelser, at voldsfilm gør voldelig osv. Eller omvendt, at medier slet ikke gør noget, at medier er en 'ren' representation eller projektion af en allerede givet virkelighed. I denne (måske naive) optik forstås medier som alene repræsentative, som diskursive eller visuelle en-til-en udlægninger, for enten en udsiger (en journalist, en blogger, en instruktør) eller en virkelighed (et nyhedsindlæg, et Wikipidea-opslag, et foto).

Men som påpeget af grene af medieforskningen, og måske især den feministiske medieforskning, er denne relation meget mere kompleks. Og når vi bevæger os over i det digitale domæne står det endnu klarere, at denne kausale forbindelse mellem medier og mennesker ikke giver mening. Snarere er de digitale medier i løbet af de sidste ti år blevet til steder, hvor man kan opholde sig, dyrke relationer og interesser. De sociale medier er således ikke repræsentationer af virkelighed, men er faktisk en udvidelse af virkeligheden og en udvidelse af subjektet, som gennem disse teknologier forlænger sig selv ind i et digitalt univers.

Feministisk teori og medieteori har inspireret hinanden i grundlæggende dekonstruktioner og gentænkninger af ikke bare repræsentation, men også hvordan (nye) medier ikke alene representerer kroppen, men også forlænger kroppen og endda dekonstruerer opfattelsen af en afgrænset og entydig krop. En forlængelse af subjektet, som bebor kroppen, men også af den materielle krop, der således giver anledning til skabelser af nye kroppe og etableringen af nye materialiseringsprocesser og nye forståelser af $\mathrm{im} /$ materialitet (se fx Sundén 2003 eller Paasonen 2010).

\section{ARTIKLERNE I DETTE NUMMER}

Artiklen "Talk dirty to me! Sexblogging som performativ intervention og medieret tilblivelse" af Marie Løntoft undersøger, hvordan det digitale medie og den kønnede og seksualiserede krop forenes i nye materialiseringsprocesser, hvor krop og medie mødes. Løntoft giver et spændende bud på, hvordan den digitale krop materialiserer sig i det, hun kalder performativ og relationel kropsmaterialitet. I artiklen stilles der skarpt på sexbloggen Sugar Tits og læsningen tager sit teoretiske afsæt hos Judith Butler og Rosi Braidotti, der sammentænkes på produktiv vis:

Mens Butler især kan belyse bloggens stiliserede kropsfremførelser og diskursive citeringsmekanismer, indfanger Braidottis perspektiv bedre effekterne af det hybride, kollektive netværk og de relationelle forbindelser, som blogmediet genererer.

I næste artikel "Crip Heroine or Mainstream Mock? -Negotiating the performances of Lady Gaga" videreføres interessen for online fankulturer og online forhandlinger af identitet, krop og køn. Men hvor første artikel interesserede sig for et mere smalt fænomen, zoomer Lise Dilling-Hansen ind på et af samtidens mainstreamkulturs mest signifikante fænomener, Lady Gaga. Dilling-Hansen positionerer sig i spæn-dingen mellem queer- og cripteori og stiller i forlængelse af disse forskningstraditioner spørgsmål om Lady Gagas subversive og transformerende effekter. I artiklens analyser af den online fankulturs diskussion af og leg med Lady Gagas forskellige performances viser Dilling-Hansen, hvordan Lady Gaga både undergraver normer og skaber rum for ikkenormative kroppe og identiteter samtidig med, at hun forbliver genkendelig inden for et mainstreamunivers ved at forblive inden for normative former.

De to artikler efterfølges af et essay. Forskerkollektivet I affekt har på deres blog udgivet forskellige "små undrende analyti- 
ske anslag" om DRs dramaserie Arvingerne (2014). Vi bringer i dette nummer de små tekster som en samlet tekst, der stiller nye spørgsmål til den populære serie under overskriften "Hvad sker der lige for DRs arvingerne?”

\section{EMILY'S VIDEO}

Fotoserien i dette nummer udgøres af screenshots fra Eva og Franco Mattes (aka 0100101110101101.org) værk “Emily’s video". Værket "Emily's video" er en samling videoklip af tilfældige frivilliges reaktioner på, hvad Eva og Franco Mattes kalder "the worst video ever". "Emily's Video" er sammensat af klip fra det såkaldte "Dark Net" (eller "Deep Web"), og i invitationen til at se med på videoen advarer Mattes: "NOTE: Emily s Video is extremely graphic and extremely violent. EXTREMELY. We don't recommend it to anybody". Selve værket består ikke af den sete video, men af de frivilliges reaktioner på denne. Videoen, får vi at vide, er efterfølgende destrueret og "You will never know what they were watching" (http://0100101110101101.org/ emilys-video/). Det er de frivillige, der bliver "skærmen", et spejlbillede af de originale optagelser, som vi aldrig kan få at se. Tilbage sidder vi med gisninger om, hvad det er, der får de optagede frivillige til at spærre øjnene op, vride sig, kigge ned, skærme ansigtet med hænderne og nærmest kaste op.

Mattes værk tematiserer det dobbelte begær i vores blik. Vi vil både se og ikke se. Samtidig skildres relationen mellem medie og menneske i dette værk som en slags voyeuristisk aktivitet, hvor vi ser andre se. Og det uundgåelige spørgsmål er: hvem ser på hvem? Med værket zoomer Mattes således ind og rykker ved grænsen mellem det subjektive og det objektive, mellem det offentlige og det private, mellem det virkelige og det virtuelle, mellem det etiske og det uetiske, og mellem medier, krop og materialitet.

Foruden de to artikler, essaeyet og foto- serien bringer vi også en artikel uden for tema. Artiklen "Assisteret befrugtning, en feministisk teoretisk udfordring?" er skrevet af Stine Willum Adrian, som undersøger, hvilken rolle assisteret reproduktion og dens teknologier har spillet i udviklingen af feministisk teori fra 1970erne til i dag. Adrian argumenterer for, at assisteret reproduktion har spillet en helt central rolle $\mathrm{i}$ de politiske, etiske og teoretiske diskussioner og forståelser af både teknologi såvel som køn og slægtskab i feministisk tænkning.

\section{Medier OG KØN}

Temanummerets to artikler og essay danner tre forskellige indgange til køn og medier. Løntofts artikel undersøger, hvordan kroppen materialiseres gennem blogmediet og viser gennem sit teoretiske rammeværk og analytiske modus, hvordan begær, seksualitet og køn ikke bare representeres $i$, men snarere bliver til $i$ samspil med mediet.

Dilling-Hansens artikel interesserer sig i mindre grad for materialisering af kroppen, men i højere grad for forhandlinger af den normative kønnede og kapable krop, som finder sted i nyere medier, der i langt højere grad end tidligere muliggør andre kommunikations- og repræsentationsformer.

Det afsluttende essay interesserer sig næsten ikke for selve mediet, men bruger $\mathrm{i}$ stedet mediet som et springbræt for at diskutere centrale tematikker i en kritisk cultural studies tradition. Her bruges mediet som en indgang til det private og det intime, og som en indgang til en analyse af samtidens forståelse af identitetsmarkerende forskelle i form af klasse, race, seksualitet og køn, men også spørgsmål om (ikke) at høre til fællesskabet i form af analyser af seriens portrættering af adoption, familie og nation.

Endeligt tegner essayet en nyere tekstlig praksis. Hvor de to artikler behandler blogmedier, så udspringer essayet direkte af dette medie. Essayet er først publiceret på 
bloggen peculiar.dk, som helt i tråd med hensigten med dette nummer kommenterer indirekte både på akademias etablerede offentligheder samt på nyhedsmediernes redaktionelle linje.

Således bliver essayet indirekte et eksempel på en modoffentlighed, hvor forskning formidles gennem nye medier til andre ikkehegemoniske akademiske og politiske offentligheder. Dette afspejles også i essayets sprog, som adskiller sig fra det klassisk akademiske, der kommer frem i temanummerets andre artikler. Teksten har således en anden rytme og komposition, som vi inviterer læseren til at tænke over som et eksempel på medieringens betydning for både form og indhold.

\section{AfSLUTNING}

Temanummerets artikler viser, at forskellige medierede fællesskaber har et stort kritisk potentiale i forhold til at udfordre hegemoniske offentligheder. Alternative offentligheder har altid eksisteret, men adgangen til og distributionen af disse fællesskaber gøres i øget grad mulig af de digitale medier.

Vi håber, at temanummeret bidrager med at synliggøre medieforskningens og kønsforskningens fælles interesser inden for både analyseobjekt og analysemetoder. I dette krydsfelt bliver gammelkendte dikotomier dekonstrueret, gentænkt og forandret. Fx dekonstrueres dikotomier mellem krop og sind og mellem krop og maskine, når genstandsfelterne mediekulturer og online fællesskaber undersøges. Her viser forsknin- gen, hvordan nye medier muliggør nye kropslige tilblivelsesformer og nye måder $a t$ gøre krop og køn på. Ligeledes står offlineonline såvel som medieret-umedieret dikotomierne for skud og temanummerets artikler viser, hvordan subjekter forlænges ind i nye "medierede" rum og udvider sig selv gennem de digitale mediers teknologi.

$$
\text { God læselyst! }
$$

\section{LITTERATUR}

- Berlant, Lauren (1997): The Queen of America Goes to Washington - essays on sex and citizenship. Duke University Press, Durham \& London. - Bissenbakker, Mons, Danbolt, Mathias og Nebeling Petersen, Michael (2014): Den skandaløse påstand om strukturel racisme. In peculiar.dk 5 . marts. http://peculiar.dk/den-skandalose-pastand-om-strukturel-racisme/

- Farrokhzad, Athena (2014): Hans raseri hyllas av danska rasister. In Aftonbladet 22. januar. http://www.aftonbladet.se/kultur/bokrecensioner/article18217879.ab

- Fraser, Nancy (1990): Rethinking the Public Sphere: A Contribution to the Critique of Actually Existing Democracy. In Social Text 25/26: 56-80. - Kember, Sarah og Joanna Zylinska (2012), Life After New Media. Mediation as Vital Process, MIT Press, Cambridge

- Paasonen, Susanna (2011): Carnal Resonance. Affect and online pornography. MIT Press, Cambridge

- Sundén, Jenny (2003): Material Virtualities. Approaching online textual embodiment. Peter Lang, New York.

- Warner, Michael (2005): Publics and Counterpublics. Zone Books, New York. 